\title{
Characterization of glucagon-like peptide-1 receptor-binding determinants
}

\section{Q Xiao, W Jeng and M B Wheeler}

Departments of Medicine and Physiology, University of Toronto, Toronto, Ontario, Canada M5S 1A8

(Requests for offprints should be addressed to M B Wheeler, Department of Physiology, University of Toronto, 1 Kings College Circle, Toronto, Ontario, Canada M5S 1A8;

Email: michael.wheeler@utoronto.ca)

\begin{abstract}
Glucagon-like peptide 1 (GLP-1) is a potent insulinotropic hormone currently under study as a therapeutic agent for type 2 diabetes. Since an understanding of the molecular mechanisms leading to high-affinity receptor (R) binding and activation may facilitate the development of more potent GLP-1R agonists, we have localized specific regions of GLP-1R required for binding. The purified $\mathrm{N}$-terminal fragment (hereafter referred to as NT) of the GLP-1R produced in either insect ( $\mathrm{Sf9}$ ) or mammalian (COS-7) cells was shown to bind GLP-1. The physical interaction of NT with GLP-1 was first demonstrated by cross-linking $\left({ }^{125} \mathrm{I}-\mathrm{GLP}-1 / \mathrm{NT}\right.$ complex band at $\left.\sim 28 \mathrm{kDa}\right)$ and secondly by attachment to $\mathrm{Ni}^{2+}-\mathrm{NTA}$ beads. The GLP-1R NT protein attached to beads bound GLP-1, but with lower affinity (inhibitory concentration $\left.\left(\mathrm{IC}_{50}\right): 4.5 \times 10^{-7} \mathrm{M}\right)$ than wild-type (WT) GLP-1R $\left(\mathrm{IC}_{50}: 5 \cdot 2 \times 10^{-9} \mathrm{M}\right)$. The low affinity of GLP-1R NT suggested that other receptor domains may contribute to GLP-1 binding. This was
\end{abstract}

supported by studies using chimeric glucosedependent insulinotropic polypeptide (GIP)/GLP-1 receptors. GIP(1-151)/GLP-1R, but not GIP(1222)/GLP-1R, exhibited specific GLP-1 binding and GLP-1-induced cAMP production, suggesting that the region encompassing transmembrane (TM) domain 1 through to TM3 was required for binding. Since it was hypothesized that certain charged or polar amino acids in this region might be involved in binding, these residues (TM2-TM3) were analyzed by substitution mutagenesis. Five mutants (K197A, D198A, K202A, D215A, R227A) displayed remarkably reduced binding affinity. These studies indicate that the NT domain of the GLP-1R is able to bind GLP-1, but charged residues concentrated at the distal TM2/ extracellular loop-1 (EC1) interface (K197, D198, $\mathrm{K} 202$ ) and in EC1 (D215 and R227) probably contribute to the binding determinants of the GLP-1R.

Fournal of Molecular Endocrinology (2000) 25, 321-335

\section{INTRODUCTION}

Glucagon-like peptide-1 (GLP-1) is an important glucoincretin hormone that is secreted from intestinal $\mathrm{L}$ cells in response to nutrient ingestion. The biologically active forms of GLP-1, (GLP-1(7-36) amide and GLP-1(7-37)), have been demonstrated to possess multiple functions, including enhancement of glucose-dependent insulin secretion, stimulation of proinsulin biosynthesis and inhibition of food intake (reviewed by Fehmann et al. 1995, Drucker 1998). Additional actions of GLP-1 may include enhancement of insulin sensitivity and the induction of $\beta$-cell protection, proliferation and differentiation (Buteau et al. 1999, Sandhu et al. 1999, Wang et al. 1999, Xu et al. 1999). Several reports indicate that GLP-1 enhances insulin secretion not only in normal subjects, but also in those with type 2 diabetes mellitus. These studies suggest that GLP-1-receptor agonists have great clinical potential for the treatment of patients with type 2 diabetes mellitus (Gutniak et al. 1992, 1996, Nathan et al. 1992, Nauck et al. 1993).

The biological functions of GLP-1 are mediated through high-affinity GLP-1 receptors (GLP-1Rs) (reviewed by Thorens 1993). This receptor, cloned initially from rat pancreatic islet cells (Thorens 1992) and subsequently from a human pancreatic insulinoma (Dillon et al. 1993), predicts a seven-transmembrane G-protein-coupled receptor (GPCR) which couples with $\mathrm{G}_{\mathrm{s}}$ and the protein kinase A (PKA) pathway to stimulate insulin 
secretion. Recent studies demonstrate that GLP-1R can also couple with other $G$ proteins, however, including $\mathrm{G}_{\mathrm{q}} 11, \mathrm{G}_{\mathrm{i}} 1$ and $\mathrm{G}_{\mathrm{i}} 2$ (Montrose-Rafizadeh et al. 1999), and activates the mitogen-activated protein kinase pathway in $\mathrm{CHO} / \mathrm{GLP}-1 \mathrm{R}$ and $\beta$-cell lines (Buteau et al. 1999, Montrose-Rafizadeh et al. 1999). This strongly suggests the possible involvement of GLP-1R in the regulation of $\beta$-cell mass via PKAdependent and PKA-independent mechanisms.

Given the therapeutic potential of GLP-1R agonists, it is important to understand how this large peptide hormone (30 amino acids) interacts with its receptor. The GLP-1R belongs to the $\mathrm{B}$-class receptor family that includes receptors for glucagon, GLP-2, glucose-dependent insulinotropic polypeptide (GIP) and secretin. A key structural feature of this receptor family is a large extracellular $\mathrm{N}$-terminal domain (hereafter referred to as NT) containing consensus sites for asparagine-linked glycosylation and six conserved cysteine residues that form putative disulfide bonds which probably contribute to the development of a highly folded structure (EMBL 1997). Pertinent to the present study are several lines of evidence that suggest that, in receptors within the B-class family, the NT domain contains putative binding sites (Holtman et al. 1995, Bergwitz et al. 1996, Gourlet et al. 1996, Graziano et al. 1996, Van Eyll et al. 1996, Wilmen et al. 1996, 1997). Our work, using a series of chimeric GLP-1 and GIP receptors, supports a role for the GLP-1R and GIP receptor (GIP R) NT domains in this process (Gelling et al. 1997). However, this work and that of others also suggest that the NT domain of the B-class receptors is insufficient for high-affinity binding or receptor activation (Buggy et al. 1995, Hjorth \& Schwartz 1996, Holtmann et al. 1995, 1996).

In the present study, we provide evidence supporting a role for the GLP-1R NT domain in ligand binding, by using a purified recombinant NT-domain protein. Moreover, using a series of chimeric receptors and a site-directed mutagenic approach, we have analyzed other domains and specific charged and polar amino acids that potentially associate with the ligand. These data demonstrate that GLP-1R binding may be complex, involving the NT domain and certain charged residues in the distal transmembrane domain 2 (TM2) and first extracellular loop 1 (EC1).

\section{MATERIALS AND METHODS}

\section{Preparation of rat GLP-1 receptor constructs}

The wild-type (WT) rat GLP-1 receptor DNA was introduced into HindIII and XhoI sites of vector
pcDNA 3 (Invitrogen, CA, USA) for mutagenesis. Mutations were introduced into the GLP-1R coding sequence by oligonucleotide-directed mutagenesis using a double-stranded template (Stratagene, CA, USA). Mutant sites were verified by dideoxy sequencing with $\mathrm{T} 7$ polymerase (Pharmacia, Uppsala, Sweden). WT and mutant receptor cDNAs were analyzed in COS-7 cells for binding assays and cAMP-accumulation determinations, as described below. Receptor mutants that were found to show little or no function (binding and cAMP accumulation) were cloned into the pEGFP vector (EGFP, enhanced green fluorescent protein) (Clonetech, CA, USA) to produce a receptor-GFP fusion protein for further analysis, as we have previously described (Salapatek et al. 1999).

NT (GLP-1R, 1-143 amino acids) and fulllength GLP-1 constructions were obtained for baculoviral expression via cloning into pFastBac1 at ApaI/NotI sites. The NT or WT GLP-1R baculovirus constructs contained c-myc and (His) 6 tags for immunodetection and purification. Cloning was verified by dideoxy sequencing. A mammalian GLP-1R NT construction was produced by cloning the NT domain (1-143 amino acids) into the pSecTag2 vector (Invitrogen) at HindIII/XhoI sites. The protein expressed from this vector was fused at the $\mathrm{N}$-terminus to the murine immunoglobulin kappa (Igא) chain leader sequence, for protein secretion, and at the $\mathrm{C}$-terminus to a peptide containing the c-myc epitope and (His) ${ }_{6}$, for detection and subsequent purification (see below).

\section{Cell culture and transfection}

COS-7 cells cultured in Dulbecco's modified Eagle's medium (DMEM) containing 10\% fetal bovine serum (FBS) and grown in $10 \mathrm{~cm}$ tissueculture dishes were transfected with plasmid DNA encoding WT, or mutant, GLP-1Rs (5 or $10 \mu \mathrm{g}$ for binding assays and cAMP assays respectively) using the diethylaminoethyl-dextran method as described previously (Wheeler et al. 1999). For baculoviral expression, the GLP-1R NT constructs were transformed into DH10 Bac-competent cells (Gibco BRL, Burlington, ON, Canada) containing a baculovirus shuttle vector (bacmid). Colonies indicative of the presence of the recombinant bacmid were selected for isolation of recombinant bacmid DNA. Recombinant bacmid DNA was isolated and purified according to the manufacturer's instructions (Gibco BRL). Sf9 cells at $60-80 \%$ confluence were infected and then harvested 4 days post-infection; this was 
followed by Western blotting to determine protein expression.

\section{Ligand binding and cAMP assays}

Synthetic human GLP-1(7-36) amide was radiolabeled with carrier-free $\mathrm{I}^{125}$ by using the chloramine- $T$ method as previously described (Gelling et al. 1997). The iodination reaction mixture was purified by reverse-phase adsorption to a C-18 Sep-pak cartridge (Waters Associates, Milford, MA, USA). COS-7 cells expressing WT and mutant receptors, $72 \mathrm{~h}$ post-transfection, were washed twice in PBS and recovered from plates with $2 \mathrm{mM}$ EDTA in PBS. Cells $\left(5 \times 10^{5} /\right.$ tube $)$ were incubated for $45 \mathrm{~min}$ at $37^{\circ} \mathrm{C}$ in binding assay buffer with ${ }^{125}$ I-GLP-1 and unlabelled GLP-1 at concentrations of $10^{-12}$ to $10^{-6} \mathrm{M}$, in a final volume of $200 \mu \mathrm{l}$. The cell suspension was centrifuged at $12000 \boldsymbol{g}$ and the cell pellet was washed with cold PBS prior to counting, as previously described (Salapatek et al. 1999). Binding assays were also performed on semi-purified plasma membranes prepared from SF-9 cells. Briefly, $100 \mu \mathrm{g}$ plasma membrane expressing NT was incubated with ${ }^{125} \mathrm{I}-\mathrm{GLP}-1$ tracer and increasing concentrations of non-radiolabelled GLP-1. After 45 min incubation at $37^{\circ} \mathrm{C}$, the mixture solution was centrifuged and the pellets counted. The protein concentration was determined with the BCA Protein Assay Reagent Kit (Pierce, Rockford, IL, USA).

For cAMP measurements, COS-7 cells expressing the WT and mutant receptors were passaged into 6- or 12-well plates $24 \mathrm{~h}$ post-transfection. After culture for an additional $48 \mathrm{~h}$, cells were washed in PBS then assay buffer (DMEM containing $1 \% \mathrm{BSA}$ ) and were then preincubated for $30 \mathrm{~min}$ at $37^{\circ} \mathrm{C}$. Cells were stimulated with GLP-1 in the presence of 3-isobutyl-1-methylxanthine (IBMX, $1 \mu \mathrm{M}$ ) for $30 \mathrm{~min}$. The cAMP was extracted using $80 \%$ ethanol and stored $\left(-20{ }^{\circ} \mathrm{C}\right)$ until radioimmunoassay. The cAMP concentrations were measured as described previously (Salapatek et al. 1999).

\section{NT-protein purification and NT- $\mathrm{Ni}^{2+}-\mathrm{NTA}$ domain binding assay}

$\mathrm{Ni}^{+2}$-NTA Superflow resin was used for purification of the (His) ${ }_{6}$-tagged NT GLP-1R fusion protein. The purification procedure was modified according to the manufacturer's instructions (Qiagen Inc., Mississauga, ON, Canada). Briefly, an aliquot of slurry of $\mathrm{Ni}^{2+}$-NTA resin was washed with sonication buffer $(50 \mathrm{mM}$ sodium phosphate, $\mathrm{pH} 7 \cdot 8,300 \mathrm{mM} \mathrm{NaCl}$ ) and incubated with cell media containing secreted NT protein or the control protein (prostate-specific antigen, PSA) for $1 \mathrm{~h}$ at room temperature. The media mixture was loaded onto a column and then washed with sonication buffer and wash buffer $(50 \mathrm{mM}$ sodium phosphate, $300 \mathrm{mM} \mathrm{NaCl}, 10 \%$ glycerol, $\mathrm{pH} 6 \cdot 0$ ). The recombinant protein was eluted with 50, 200 and $500 \mathrm{mM}$ imidazole. The fractions were collected and analyzed by Western blotting as described below. For binding assays, the cell media containing GLP-1R NT or PSA were incubated with $\mathrm{Ni}^{2+}$-NTA resin for $1 \mathrm{~h}$ at room temperature followed by three washes with wash buffer. The resin beads containing NT or PSA protein $(100 \mu \mathrm{g}$ protein) were then incubated with ${ }^{125}$ I-GLP-1 for $45 \mathrm{~min}$ in the presence or absence of unlabelled GLP-1. After a centrifugation step, the pellet was washed with cold PBS and the level of specific radioactivity determined.

\section{Western blotting and cross-linking}

Purified samples $(10 \mu \mathrm{g}$ protein) were separated by $10 \%$ SDS-PAGE and transferred to a nitrocellulose membrane (Bio-Rad Laboratories, Hercules, CA, USA). After an overnight incubation with blocking buffer, the membrane was washed three times with TBS-T buffer $(0.05 \mathrm{M}$ Tris, $0.15 \mathrm{M} \mathrm{NaCl}, 0 \cdot 1 \%$ $(\mathrm{v} / \mathrm{v})$ Tween) before incubation with 1:5000 primary antibody (anti-myc or anti-His; Invitrogen) followed by an anti-mouse or an anti-rabbit horseradish peroxidase-conjugated secondary antibody (1:5000) respectively. Blots were then detected with ECL reagents according to the manufacturer's instructions (Amersham Pharmacia Biotech UK Ltd, Amersham, Bucks, UK). For cross-linking, plasma membranes $(100 \mu \mathrm{g})$ were incubated with ${ }^{125}$ I-GLP-1 (50 000 c.p.m.) in Hepes buffer $(50 \mathrm{mM}, \mathrm{pH} 7 \cdot 5)$ containing $0.02 \% \mathrm{BSA}$ for $45 \mathrm{~min}$ at $37^{\circ} \mathrm{C}$ in the presence or absence of $1-10 \mu \mathrm{M}$ GLP-1. The membrane mixtures were centrifuged at $12000 \mathrm{~g}$ for $5 \mathrm{~min}$ at $4{ }^{\circ} \mathrm{C}$ and pellets were resuspended in $10 \mathrm{mM}$ Hepes $(\mathrm{pH} \mathrm{7.5)}$ containing $0.02 \%$ BSA. The cross-linker disuccinimidyl suberate (DSS) in dimethylsulfoxide was added to the solution at a final concentration of $1 \mathrm{mM}$. After an incubation period $(10 \mathrm{~min})$ at $4{ }^{\circ} \mathrm{C}$, an ammonium acetate solution was added (final concentration $10 \mathrm{mM}$ ) to quench the reaction. Membranes were spun at $12000 \mathrm{~g}$ for $5 \mathrm{~min}$ at $4{ }^{\circ} \mathrm{C}$ and the pellets were resuspended in Hepes buffer $(10 \mathrm{mM}, \mathrm{pH} 7 \cdot 5)$ containing $0 \cdot 02 \%$ BSA. The mixture was incubated for an additional $30 \mathrm{~min}$, centrifuged and then resuspended in $10 \mathrm{mM}$ sodium phosphate buffer 
containing 2\% SDS (pH 7-5). Samples were prepared for SDS-PAGE. Gels were dried and exposed to film for 3-14 days using one intensifying screen.

\section{Confocal microscopy}

On glass cover-slips in six-well plates, COS-7 cells were grown and transfected with plasmids encoding EGFP-tagged WT or selected mutant GLP-1R constructions; $72 \mathrm{~h}$ post-transfection, the cells were analyzed by confocal microscopy as described previously (Salapatek et al. 1999).

\section{Data analysis}

All values are expressed as the means \pm s.E.M. of at least three independent experiments. Statistical analyses were performed using the Student's paired $t$-test (Instat; GraphPad Software, San Diego, CA, USA). $P<0 \cdot 05$ was taken as the level of significant difference.

\section{RESULTS}

\section{Sf9-cell NT-domain expression}

The NT domain of the GLP-1R cloned into $\mathrm{pFastBacHTb}$ and $\mathrm{pFastBac1}$ was transformed into DH10 Bac-competent cells containing a baculoviral shuttle vector. Recombinant bacmids were isolated and used to infect Sf9 cells as described in the Materials and Methods. Two days post-infection, the NT-domain protein was characterized by Western blot analysis (Fig. 1). The NT domain expressed without the putative GLP-1R leader sequence (-LS; see Fig. 2) appeared as a $\sim 17 \mathrm{kDa}$ product (Fig. 1B), whereas the NT domain expressed with the leader sequence (+LS; Fig. 1C) appeared as two larger isoforms, $\quad(\sim 21$ and $\sim 24 \mathrm{kDa}$; see lanes 2 and 3 ). The NT-domain protein with or without the LS was treated with PNGase F (to cleave N-linked oligosaccharides): NT(-LS) was not affected, but NT(+LS) collapsed to a single $21 \mathrm{kDa}$ product (lane 4 ). To clarify the location of the expressed non-glycosylated and glycosylated NT-domain proteins in Sf9 cells, the infected cells were fractionated into cytosolic and plasma-membrane fractions by using sucrose-gradient centrifugation followed by Western blot analysis. As shown in Fig. 1D, the glycosylated (+LS) NT GLP-1R was mainly associated with the plasma-membrane fraction, there being minimal expression in the cytosol (left panel, lanes 1 and 2). However, the nonglycosylated NT domain was found in both the plasma-membrane and the cytosolic fractions (right panel, lanes 1 and 2). The fractions obtained from untransfected cells contained no specific signal (lanes 3 and 4 ).

\section{Sf9 NT-domain binding and cross-linking}

In order to determine the potential physical interaction between GLP-1 and the NT domain of GLP-1R, the NT was covalently cross-linked to ${ }^{125}$ I-GLP-1 by using DSS (see the Materials and Methods). The complex solution was subsequently separated by SDS-PAGE. A ligand-binding protein with a molecular mass of $28 \mathrm{kDa}$ was observed with glycosylated NT GLP-1R (Fig. 3, panel 2). This band was competed with excess GLP-1 $(10 \mu \mathrm{M})$, demonstrating the specificity of the peptide for the NT. Interestingly, larger specific bands were observed, suggesting that the NT domain may complex as a dimer, or perhaps as larger complexes (Fig. 3, panel 2). Cells transfected with full-length WT GLP-1R exhibited a strong interaction, as demonstrated by an intense signal of the predicted size $(\sim 65 \mathrm{kDa})$. As expected, the intensity of the ligand-binding complex was dramatically reduced in the presence of GLP-1 (10 $\mu \mathrm{M})$ (Fig. 3, panel 3). Non-glycosylated NT-domain protein and protein obtained from control cells (Fig. 3, panels 1 and 4 respectively) did not form detectable complexes. These data suggest that the GLP-1R NT domain is capable of interacting with GLP-1, but that the interaction is probably weaker than that of the intact GLP-1R (given that approximately equal amounts of protein were used in these studies). These data also suggest that the NT domain may, in part, contribute to receptor dimerization, which has been described for members of the A-class receptor family ( $\mathrm{Ng}$ et al. 1996, Han \& Hampson 1999, Jordan \& Devi 1999).

In order to test the hypothesis that the NT domain binds GLP-1, but with lower affinity, the plasma-membrane fraction of $\mathrm{Sf} 9$ cells expressing the NT was used in a competitive displacement binding assay. WT GLP-1R membranes $(100 \mu \mathrm{g})$ showed typical GLP-1 binding $\left(\mathrm{IC}_{50}=12 \mathrm{nM}\right)$. The glycosylated NT domain of GLP-1R showed a lower binding affinity compared with the full-length GLP-1R, specific displacement being observed at GLP-1 concentrations between $0 \cdot 1$ and $1 \mu \mathrm{M}$ (data not shown). The non-glycosylated NT domain showed no detectable displacement at $1 \mu \mathrm{M}$ GLP-1 (data not shown), in agreement with cross-linking studies that suggest that the $\mathrm{NT}(-\mathrm{LS})$ protein is non-functional. 
A
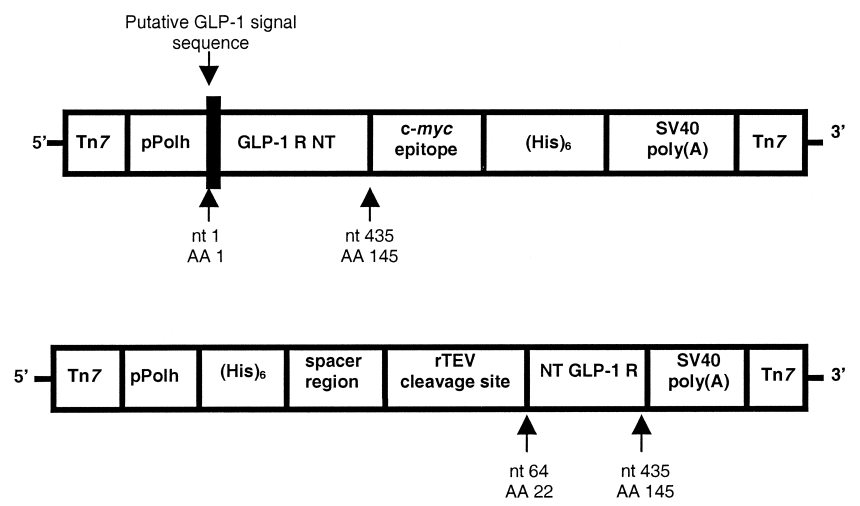

B

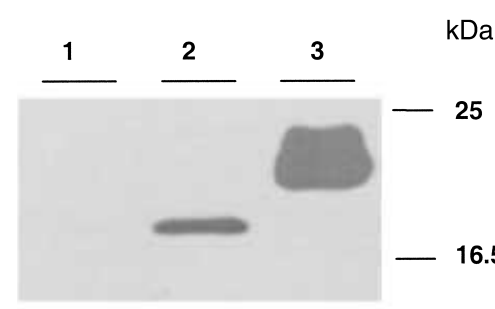

D

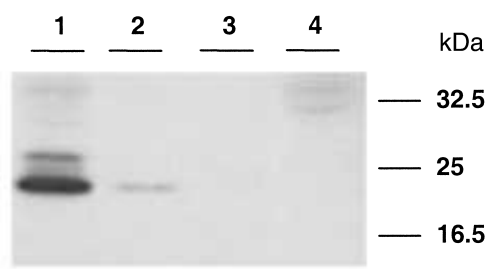

C
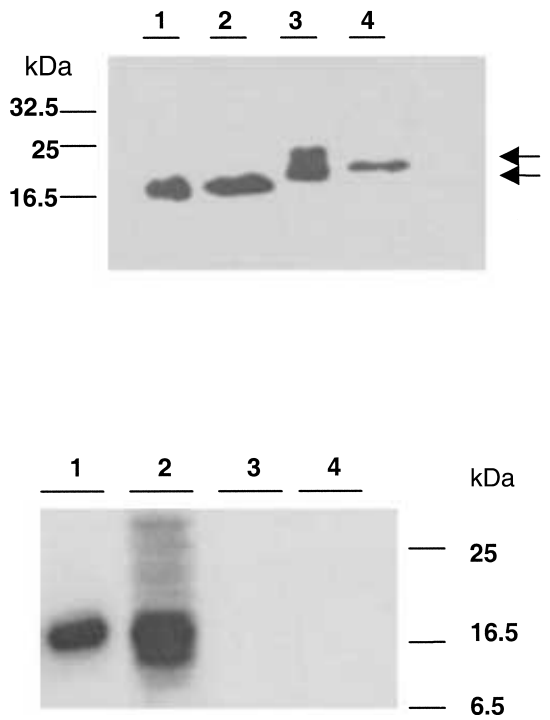

FIGURE 1. Expression of the GLP-1R NT domain generated in Sf9 cells.

(A) Schematic diagram of the constructs $(\operatorname{Tn} 7$, transposon 7; pPolh, polyhedrin promoter) encoding the NT cDNA with (top) and without (bottom) the putative leader sequence (LS). (B) Expression of the GLP-1R NT domain in infected Sf9 cells was analysed by Western blotting: lane 1, uninfected Sf9 cells (control); lane 2, the NT domain expressed without the putative LS appears as a $\sim 17 \mathrm{kDa}$ band; lane 3, the NT domain (with the LS), which appears as two isoforms $(\sim 21 \mathrm{kDa}$ and $\sim 24 \mathrm{kDa}$ ). (C) Deglycosylation of protein samples obtained from infected Sf9 cells was performed by treatment with peptide-N-glycosylase (PNGase) F followed by Western blot analysis. GLP-1R NT without the LS (lanes 1 and 2) and with the LS (lanes 3 and 4) were untreated (lanes 1 and 3) or treated (lanes 2 and 4) with PNGase F. The glycosylated form and the non-glycosylated form are indicated by the upper and lower arrows respectively. (D) The locations of the expressed non-glycosylated and glycosylated NTs were determined by analyzing the cytosolic and plasma-membrane fractions obtained by sucrose-gradient centrifugation. Left panel: glycosylated NT was associated with the plasma membrane (lane 1) and showed minimal expression in the cytosol (lane 2). Right panel: non-glycosylated NT was present in both the plasma membrane (lane 1) and cytosolic fractions (lane 2).

Plasma-membrane and cytosolic fractions of untransfected Sf9 cells are shown in lanes 3 and 4 respectively, in both panels. Molecular mass markers are indicated beside each panel. 


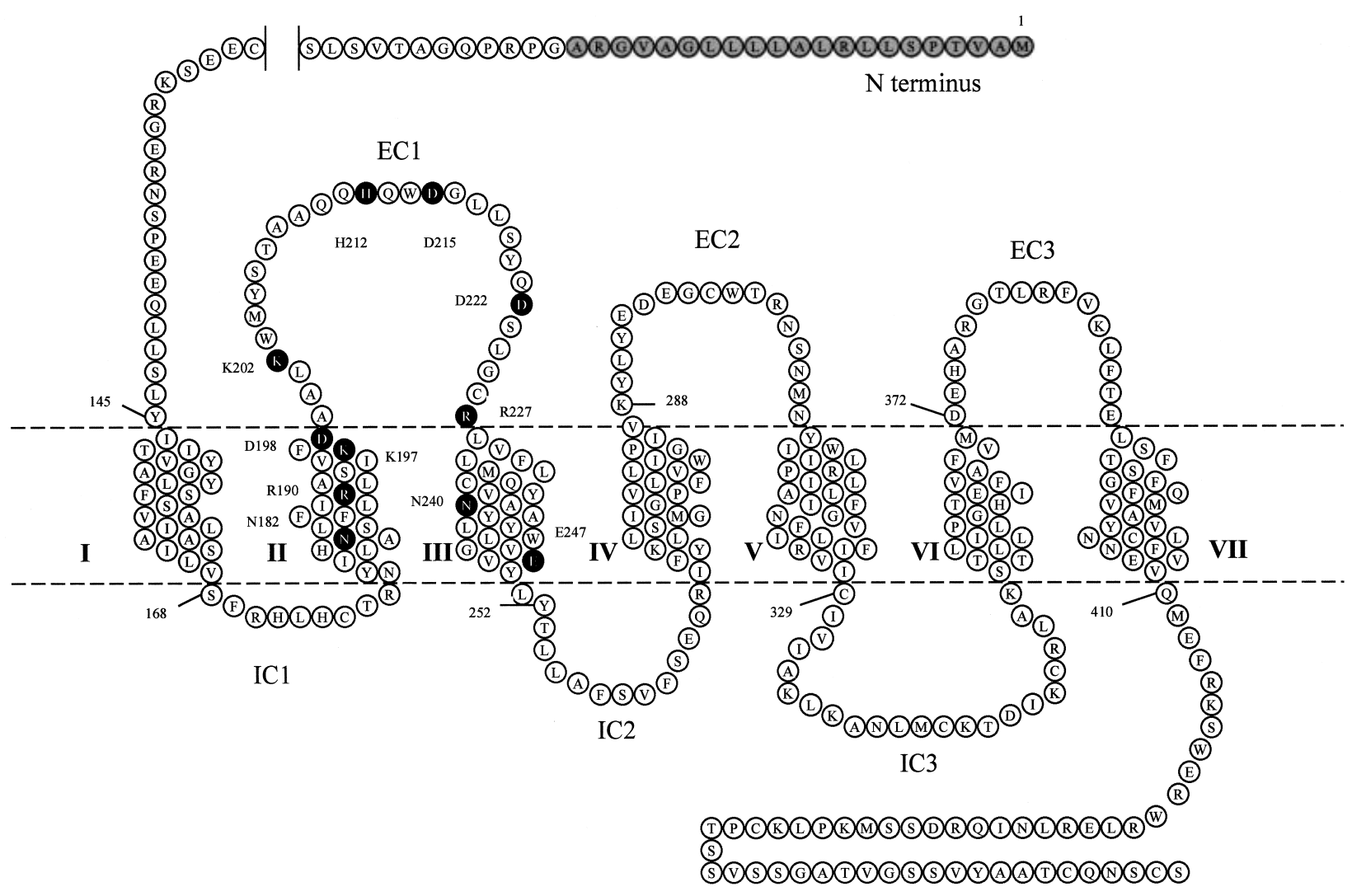

$\mathrm{C}$ terminus

463

FIGURE 2. Schematic representation of the predicted structure of the rat GLP-1R. The GLP-1 receptor is predicted to contain an NT, three EC and IC loops, seven TM domains and a carboxy-terminal (CT) tail. Amino acids are identified by the one-letter code. $\bullet$, represent the amino acids that were substituted by $\mathrm{A}$ in this study. $\bigcirc$ represent the leader sequence.

\section{GLP-1R NT purification and binding}

To isolate a GLP-1R NT domain that is produced in mammalian cells and does not require a detergent solubilization step, COS-7 cells were transfected with the construct pSec NT GLP-1R (Fig. 4A). Since this construct is designed to produce a secretable protein, in theory the NT domain should accumulate in culture media. Three days posttransfection, soluble protein containing the myc(His) ${ }_{6}$ tag was purified using an $\mathrm{Ni}^{2+}$-NTA Superflow column and eluted with increasing concentrations of imidazole $(50-500 \mathrm{mM})$. The elution fractions were analysed by Western blotting using anti-myc antibody. As shown in Fig. 4B, a strong protein band of molecular mass $30 \mathrm{kDa}$ (lanes 2 and 3 ) was observed in the eluate fractions (50 and $200 \mathrm{mM}$ imidazole), but was not present in control cell media, unpurified media or washing buffer. Since the deduced molecular masses of the NT domain and the vector fusion protein were approximately $22 \mathrm{kDa}$ and $5 \mathrm{kDa}$ respectively, the larger apparent size of the protein could be attributed to post-translational glycosylation. Additionally, the appearance of the $80 \mathrm{kDa}$ band may represent non-specific binding with components present in the culture medium (since it was also present in the control fraction).

To determine if the purified NT protein obtained from a mammalian expression system was able to bind GLP-1, the NT-domain protein was absorbed onto $\mathrm{Ni}^{2+}$-NTA beads by using the procedure described in the Materials and Methods (see Fig. 4C) to perform a competitive displacement assay. When compared with the non-specific binding $(2668 \pm 276$ c.p.m./tube, $n=3)$, represented by the counts obtained from the control beads attached to an equivalent amount of expressed PSA control 


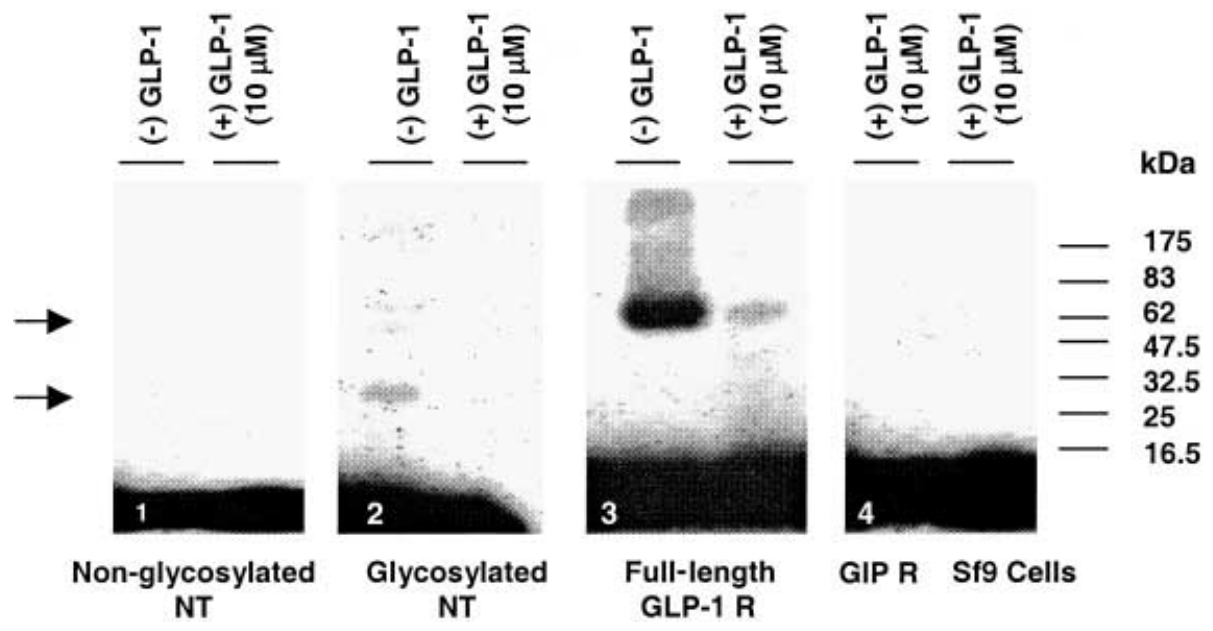

FIGURE 3. GLP-1R NT cross-linking and binding to GLP-1. Chemical cross-linking of ${ }^{125}$ I-GLP-1 to NT, without the LS (panel 1) and with the LS (panel 2), and full-length GLP-1R (lane3) expressed in Sf9 plasma membrane in the presence or absence of GLP-1 $(10 \mu \mathrm{M})$. Panel 2: a major ${ }^{125}$ I-GLP-1/NT complex $(28 \mathrm{kDa})$ was revealed (lower arrow) which was diminished with excess GLP-1. Panel 3: an $\sim 65 \mathrm{kDa}$ band indicative of the ${ }^{125} \mathrm{I}-\mathrm{GLP}-1 / \mathrm{GLP}-1 \mathrm{R}$ complex (upper arrow) was also diminished with $10 \mu \mathrm{M}$ GLP-1. Non-glycosylated NT, GIP R or uninfected Sf9 plasma membranes did not bind ${ }^{125}$ I-GLP-1 (panels 2 and 4). Molecular mass markers are shown to the right of the panels.

protein $(\sim 100 \mu \mathrm{g})$, the NT protein was found to be able to bind ${ }^{125}$ I-GLP-1 $(3690 \pm 627$ c.p.m./tube, $n=3)$. The value for specific binding was $1021 \pm 218$ c.p.m./tube. Since the radioactivity associated with beads with attached PSA could not be displaced with GLP-1 at concentrations as high as $10 \mu \mathrm{M}$ $(2668 \pm 276$ vs $2517 \pm 171, n=3)$, it was considered to be background radioactivity. In contrast, with NT protein, specific binding was inhibited in the presence of graded increases in unlabelled GLP-1 with an $\mathrm{IC}_{50}$ of $450 \pm 35 \mathrm{nM}$ (Fig. 4D). This value was remarkably high relative to that of the full-length GLP-1R expressed in COS-7 cells $(5 \cdot 3 \pm 1 \cdot 9 \mathrm{nM})$.

\section{Chimeric GIP/GLP-1 receptor}

The relatively low affinity of the GLP-1R NT for GLP-1 suggests that other domains within the GLP-1R contribute to high-affinity binding. In order to test this hypothesis, a chimeric-receptor strategy was employed. Although the GIP receptor shares approximately $40 \%$ homology with GLP-1R, we have shown that neither binds or is activated by the other's ligand, at concentrations as high as $1 \mu \mathrm{M}$. Two chimeric receptors (see Fig. 5A), GIP(1-151)/GLP-1R (CH3) and GIP(1-222)/ GLP-1R (CH4), were produced and expressed in
COS-7 cells. Previous studies showed that both of these receptor chimeras efficiently bound, and were activated by, GIP (Gelling et al. 1997). Interestingly, we found that the GIP(1-151)/GLP-1R construct $(\mathrm{CH} 3)$ also bound GLP-1 with a high affinity relative to that of WT GLP-1R $(1 \cdot 4 \pm$ $1 \cdot 0 \mathrm{nM}$ vs $3 \cdot 8 \pm 0 \cdot 8 \mathrm{nM}$; Fig. $5 \mathrm{~B})$, but the maximum binding $\left(\mathrm{B}_{\max }\right)$ for ${ }^{125} \mathrm{I}-\mathrm{GLP}-1$ was reduced approximately 12 -fold (376 \pm 43 vs $3932 \pm 1234$ c.p.m./tube). Of further interest was the observation that this chimeric receptor was still activated by GLP-1 $(10 \mathrm{nM})$, with a $\sim 2 \cdot 5$-fold increase over basal cAMP production (Fig. 5D). In contrast, GIP(1-222)/GLP-1 R (CH4) lost the ability to bind GLP-1 or to lead to any measurable increase in cAMP accumulation, despite the observation that both $\mathrm{CH} 3$ and $\mathrm{CH} 4$ were bound and activated efficiently by GIP (Fig. $5 \mathrm{C}$ and $\mathrm{E}$; $\mathrm{CH} 3$ : $\mathrm{B}_{\max }=$ $5150 \pm 1424 \quad$ c.p.m./tube, $\quad \mathrm{IC}_{50}=18 \cdot 3 \pm 1 \cdot 5 \mathrm{nM}$; CH4: $\quad \mathrm{B}_{\max }=1636 \pm 466$ c.p.m./tube, $\quad \mathrm{IC}_{50}=2 \cdot 8 \pm$ $0.9 \mathrm{nM})$. Results obtained from the $\mathrm{CH} 3$ chimeric receptor suggested that specific domains and amino acid residues distal to the NT contribute to GLP-1 binding and receptor activation. The fact that $\mathrm{CH} 4$ apparently did not interact with GLP-1 suggested that the TM1-TM3 region of the receptor contains these important moieties. The studies described below address this hypothesis. 
A

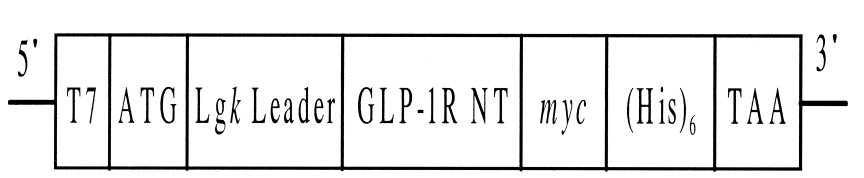

C

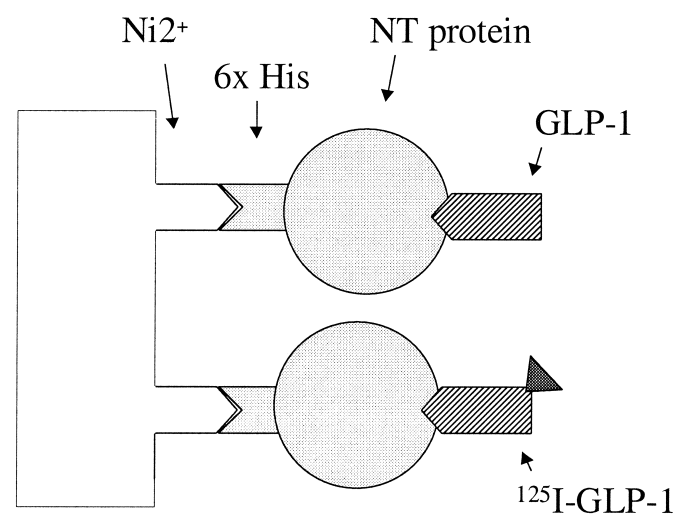

B

kDa

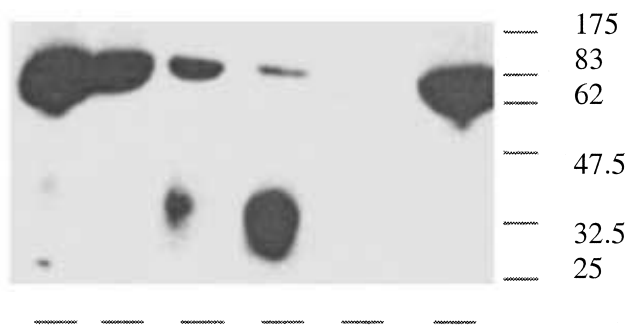

$\begin{array}{llllll}1 & 2 & 3 & 4 & 5 & 6\end{array}$

D

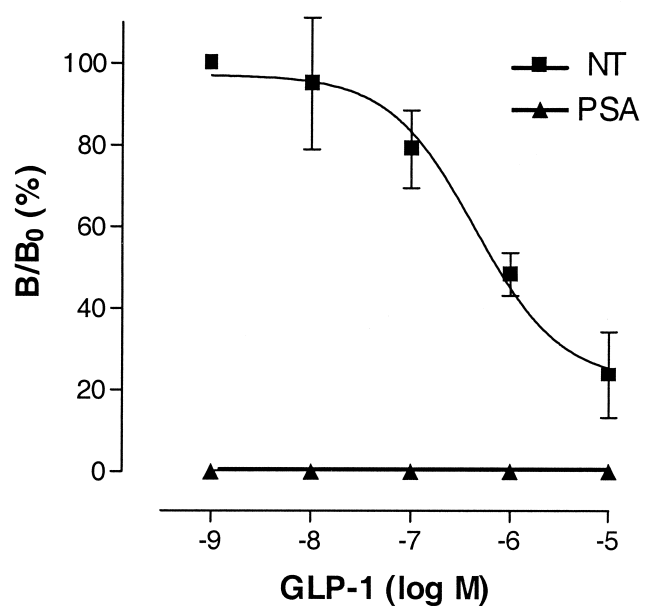

FIGURE 4. Expression and functional analysis of the GLP-1R NT domain secreted from COS-7 cells. (A) Schematic representation of the NT-pSecTag construct. Expressed NT was fused at the N-terminus to the murine Igk chain LS, for protein secretion, and at the C-terminus to a peptide containing c-myc and (His) 6 epitopes, for purification and detection. (B) Secreted NT protein was purified on an $\mathrm{Ni}^{2+}-\mathrm{NTA}$ column and sequentially eluted with imidazole after a complete wash, followed by Western blot analysis. Lanes: 1, unpurified cell media; 2, wash fraction (after loading of media onto the column); 3-5, the fractions sequentially eluted by 50 , 200 and $500 \mathrm{mM}$ imidazole; 6, control (fresh DMEM media). Molecular mass markers are shown to the right of the panel. (C) The diagram represents the competitive binding assay of purified NT protein. NT protein with the (His) ${ }_{6}$ tag associated with $\mathrm{Ni}^{2+}$-NTA beads bound ${ }^{125}$ I-GLP-1 and cold GLP-1. (D) Radioligand binding analysis of purified NT. The specific binding was determined by subtraction of non-specific counts (determined using the PSA control; see the Materials and Methods) from the total counts. Data are means \pm S.E.M. of three independent experiments. 
A

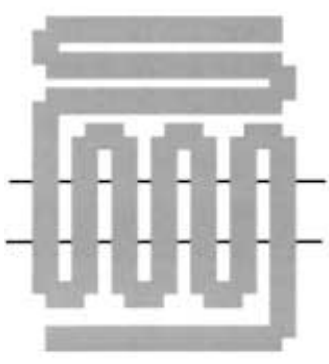

GIP R

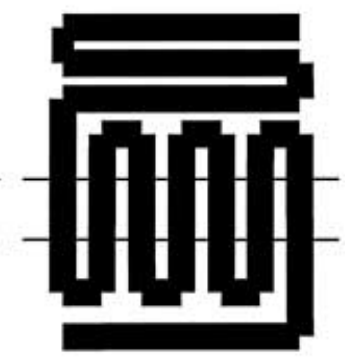

GLP-1R

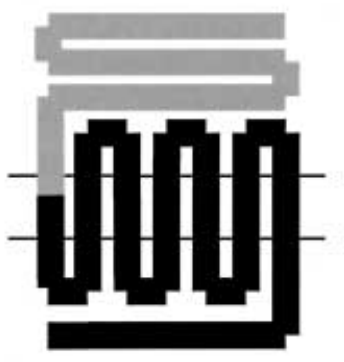

$\mathrm{CH} 3$

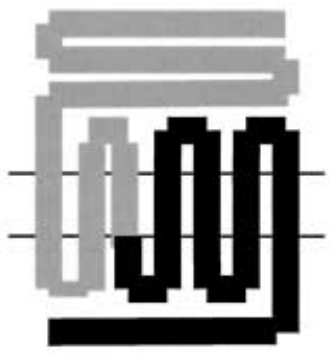

$\mathrm{CH} 4$
B

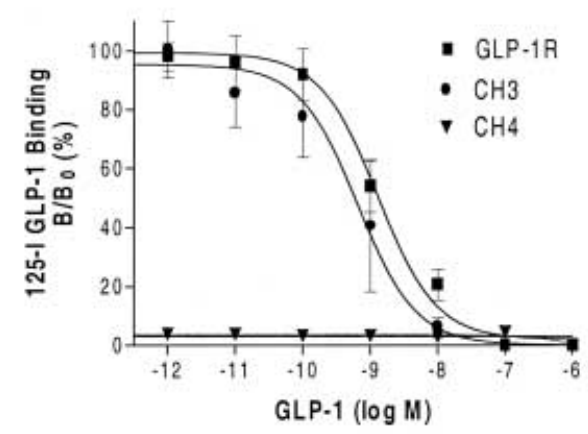

D

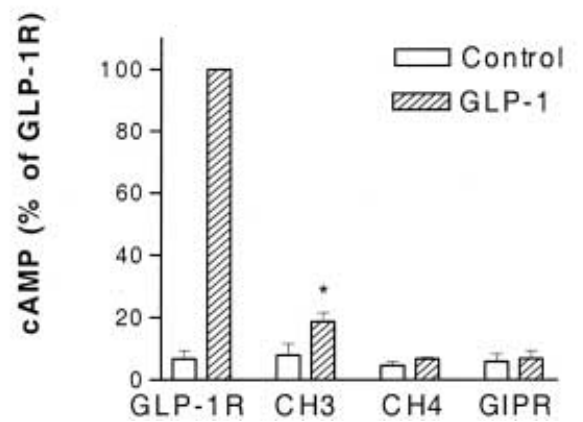

C

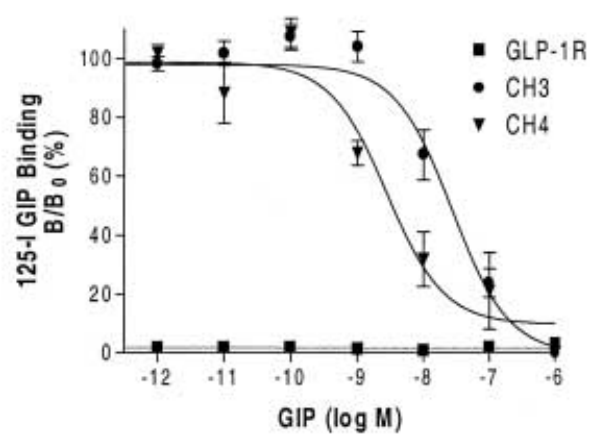

$\mathbf{E}$

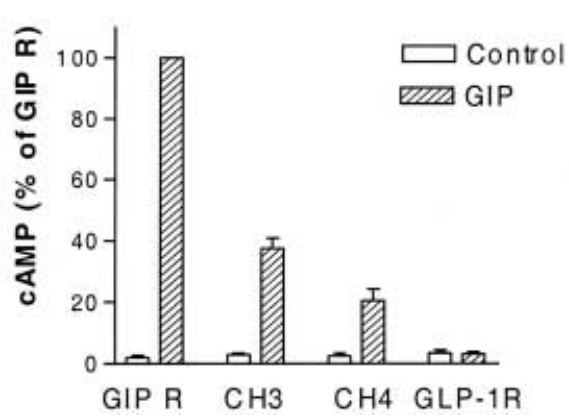

FIGURE 5. Analysis of binding and signaling of WT and chimeric GIP/GLP-1 R expressed in COS-7 cells. (A) Schematic representations of GIP R, GLP-1R, and two chimeric receptors GIP(1151)/GLP-1R (CH3) and GIP(1-222)/GLP-1R (CH4). (B) Binding of the chimeric receptors was examined for ${ }^{125}$ I-GLP-1 binding in COS-7 cells compared with GLP-1R. (C) Binding of the chimeric receptors was examined for ${ }^{125}$ I-GIP binding in COS-7 cells compared with GLP-1R. (D) Analysis of GLP-1 (100 nM) stimulated cAMP production in cells expressing GIP R, GLP-1R and chimeric receptors. (E) Analysis of GIP $(100 \mathrm{nM})$ stimulated cAMP production in cells expressing GIP R and chimeric receptors. Values are the means \pm s.E.M. of three different transfection experiments $(* P<0 \cdot 05)$. 
TABLE 1. Receptor binding and activation in transfected COS-7 cells

\begin{tabular}{|c|c|c|c|c|}
\hline & Receptor & $\begin{array}{l}\mathbf{I C}_{50} \\
(\mathrm{nM})\end{array}$ & $\begin{array}{l}\text { cAMP } \\
(\% \text { of } \mathrm{WT})\end{array}$ & $\begin{array}{l}\mathbf{B}_{\max } \\
(\% \text { of WT) }\end{array}$ \\
\hline ofi & WT GLP-1R & $5 \cdot 3 \pm 1 \cdot 9$ & 100 & 100 \\
\hline TM2 & $\begin{array}{l}\text { N182A } \\
\text { R190A } \\
\text { K197A }\end{array}$ & $\begin{array}{l}2 \cdot 3 \pm 0 \cdot 8 \\
>100 \\
26 \cdot 9 \pm 8 \cdot 2\end{array}$ & $\begin{array}{l}35 \cdot 8 \pm 14 \cdot 6 \\
26 \cdot 9 \pm 8 \cdot 2 \\
25 \cdot 0 \pm 23 \cdot 5\end{array}$ & $\begin{array}{l}23 \cdot 7 \pm 6 \cdot 7 \\
20 \cdot 5 \pm 5 \cdot 4 \\
30 \cdot 4 \pm 8 \cdot 0\end{array}$ \\
\hline $\mathrm{EC}$ & $\begin{array}{l}\text { D198A } \\
\text { K202A } \\
\text { H212A } \\
\text { D215A } \\
\text { D222A } \\
\text { R227A }\end{array}$ & $\begin{aligned} 52 \cdot 4 & \pm 18 \cdot 4 \\
20 \cdot 3 & \pm 10 \cdot 0 \\
2 \cdot 5 & \pm 0 \cdot 8 \\
22 \cdot 7 & \pm 8 \cdot 4 \\
6 \cdot 5 & \pm 3 \cdot 9 \\
> & 100\end{aligned}$ & $\begin{aligned} 19 \cdot 9 & \pm 3 \cdot 3 \\
71 \cdot 4 & \pm 8 \cdot 7 \\
102 \cdot 4 & \pm 19 \cdot 7 \\
56 \cdot 7 & \pm 16 \cdot 3 \\
81 \cdot 9 & \pm 41 \cdot 3 \\
90 \cdot 2 & \pm 32 \cdot 0\end{aligned}$ & $\begin{array}{l}16 \cdot 2 \pm 1 \cdot 7 \\
44 \cdot 7 \pm 8 \cdot 6 \\
92 \cdot 9 \pm 4 \cdot 1 \\
50 \cdot 9 \pm 12 \cdot 1 \\
94 \cdot 5 \pm 12 \cdot 6 \\
31 \cdot 1 \pm 6 \cdot 5\end{array}$ \\
\hline TM3 & $\begin{array}{l}\text { N240A } \\
\text { E247A }\end{array}$ & $\begin{array}{l}>100 \\
\quad 6 \cdot 0 \pm 1 \cdot 7\end{array}$ & $\begin{array}{c}8 \cdot 4 \pm 2 \cdot 7 \\
63 \cdot 6 \pm 16 \cdot 8\end{array}$ & $\begin{array}{l}14 \cdot 4 \pm 4 \cdot 6 \\
39 \cdot 0 \pm 5 \cdot 5\end{array}$ \\
\hline
\end{tabular}

\section{Ligand binding of GLP-1R substitution mutants}

Chimeric receptor studies (Fig. 5) suggested that TM1-TM3 contain important residues for binding. Since it is predicted that receptor-ligand interaction within the B-class family and its respective peptides may involve interactions between charged residues (salt bridge formation), a series of alanine (A) substitutions targeting these charged and polar residues was performed (see Fig. 2). The effects of receptor mutations on GLP-1 binding properties and on receptor activation were analyzed. Mutants N182A, H212A, D222A and E247A did not significantly change receptor binding affinity $\left(\mathrm{IC}_{50}=2 \cdot 3 \pm 0 \cdot 8, \quad 2 \cdot 5 \pm 0 \cdot 8, \quad 6 \cdot 5 \pm 3 \cdot 0\right.$ and $6 \cdot 0 \pm$ $1.7 \mathrm{nM}$ respectively; see Table 1 , Fig. $6 \mathrm{~A}$ and B) relative to that of the WT receptor $(5 \cdot 2 \pm$ $1.9 \mathrm{nM})$. N182A and E247A did display comparable decreases in both $\mathrm{B}_{\max }$ and cAMP accumulation, which are indicative of less efficient cell-surface expression (Table 1). In contrast, K197A, D198A, K202A, D215A and R227A displayed remarkable reductions in binding affinity $\left(\mathrm{IC}_{50}\right.$ values $4-$ to 20-fold higher than that of the WT GLP-1R; Table 1 , Fig. $6 \mathrm{~A}$ and $\mathrm{B})$, and this was accompanied by a reduced $B_{\max }$ value (Table 1 ). These data suggest that K197, D198, K202, D215 and R227 directly (by disrupting the specific interaction between the peptide and receptor) or indirectly (by changing the general conformation of the receptor) contribute to high-affinity GLP-1R binding. Mutant receptors R190A and N240A had extremely low values for $\mathrm{B}_{\max }$ as well as cAMP accumulation $(<27 \%$ of that of the WT receptor), suggesting that these residues are essential for ligand binding and/or cell-surface expression. To determine if they, along with the
WT GLP-1R, were appropriately targeted to the plasma membrane, pGLP-1R-EGFP constructions were generated and transfected into COS-7 cells for observation using confocal microscopy (Fig. 7). COS-7 cells expressing the WT GLP-1R displayed typical high-density fluorescence at the plasma membrane. In contrast, the expression of R190A or N240A was similar to that of pEGFP alone, showing a cytosolic pattern of expression, which suggests that these mutants were not targeted to the plasma membrane. As such, it was not possible to assess their contribution to surface-receptor binding. In contrast, N182A, which exhibited normal affinity but reduced expression, was appropriately targeted to the plasma membrane, but the fluorescence intensity was reduced relative to that of the WT GLP-1R (Fig. 7C).

\section{DISCUSSION}

Precise and efficient signal transduction through a GPCR requires highly specific interactions with its ligand. Varied methodological approaches have shown that each of the receptor classes displays a unique set of binding characteristics. The receptors for the glycoprotein hormones contain large NT domains that provide sites for high-affinity binding (reviewed by $\mathrm{Ji}$ et al. 1998). In contrast, the receptors for biogenic amines contain very small extracellular NT domains, so their binding elements are concentrated deep within the hydrophobic transmembrane regions. The members of the secretin B-class family of receptors have been less well studied, but, nevertheless, there is increasing evidence to suggest that several domains within the receptor interact with its ligand and that the binding characteristics may be quite complex and receptor-type specific. Given the great interest in designing small molecule-based GLP-1R agonists that are more suitable for the treatment of type 2 diabetes, it is important to understand the key structural features of the receptor that are required for receptor binding and activation. The present studies support the hypothesis that high-level binding and specificity require multiple contacts, between the receptor and GLP-1, that involve the receptor NT, TM2 and EC1.

The GLP-1R, like other members of the secretin B-receptor family, contains a moderately large NT domain (predicted size 146 amino acids) that probably attains a highly folded structure. Several reports have now provided evidence that the NT domain does, indeed, play some role in the binding process, but it is unclear if the NT alone is sufficient to promote high-affinity binding. Those studies 


\section{A}

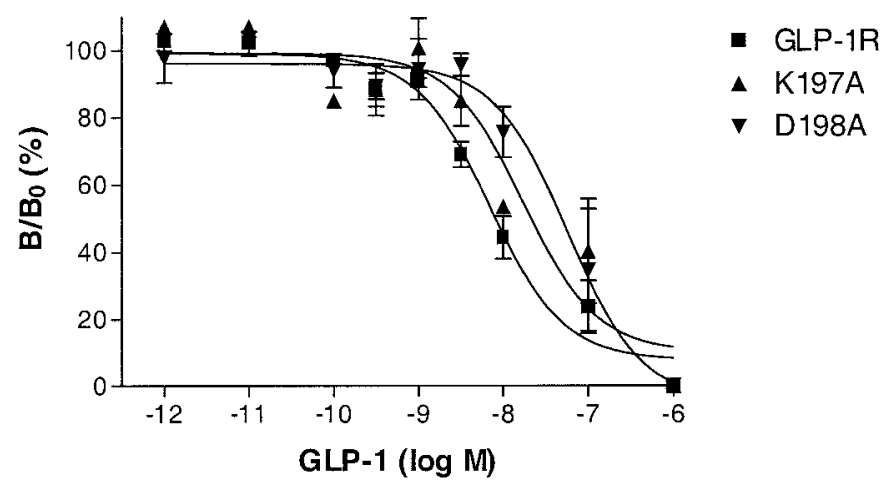

B

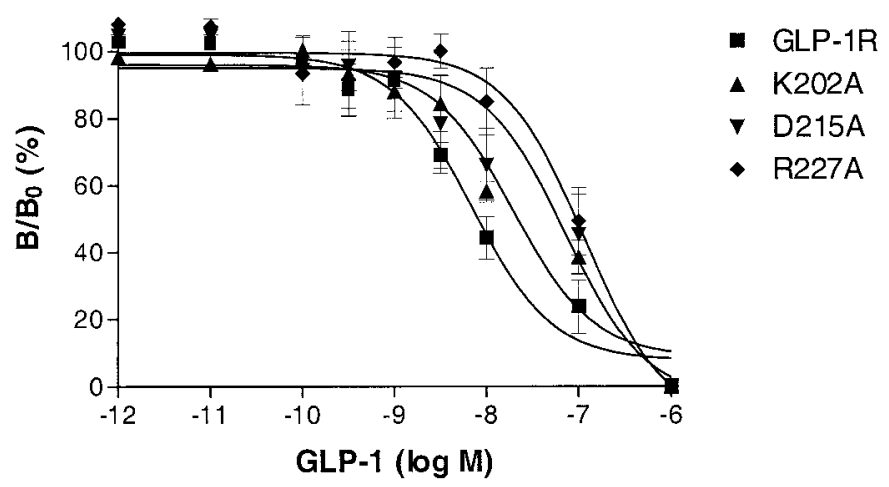

FIGURE 6. Binding analysis of mutant GLP-1Rs in COS-7 cells. (A)

Binding ability of the TM2 and (B) EC1 loop GLP-1R mutants

examined for ${ }^{125}$ I-GLP-1 binding. Data are the means \pm s.E.M. of three independent experiments.

using site-directed mutagenesis demonstrate that residues within the GLP-1R NT, when mutated, cause loss-of-function mutants, or, in the case of K38 or R40, a significant decrease in the $K_{\mathrm{d}}$ value (Van Eyll et al. 1996, Wilmen et al. 1997). One of the most convincing indications that the NT does interact with GLP-1, however, came from Wilmen et al. (1996), who used a non-glycoslylated recombinant GLP-1R NT fragment. After chemical refolding of the NT protein, it was capable of being cross-linked to GLP-1, but the affinity of the peptide for the receptor fragment was not determined. In the present study, the GLP-1R NT was examined using two approaches. First, the NT domain, with or without the putative LS, was generated via baculoviral expression (Sf9 cells). Only the NT with the LS was glycosylated (presumably correctly folded) and was capable of being cross-linked to GLP-1 (Fig. 3). Secondly, a GLP-1R NT secreted from COS-7 cells and attached to $\mathrm{Ni}^{2+}$-NTA beads could also be shown to bind GLP-1 (Fig. 4D). In both cases, however, binding was sufficiently weak to suggest that the NT domain alone was perhaps incapable of the full 

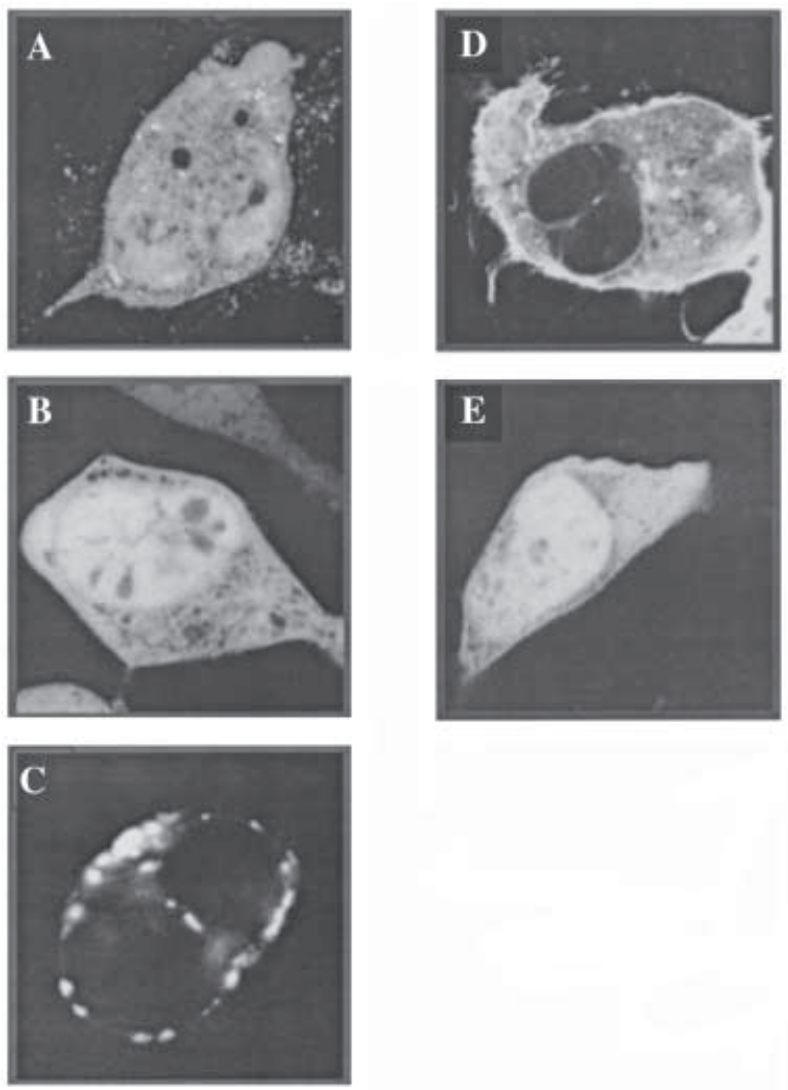

FIGURE 7. Localization of GLP-1R expression in COS-7 cells. Transfected cells expressing EGFP-tagged receptor mutants were analysed by confocal microscopy 3 days post-transfection. (A) GFP vector control, (B) R190A mutant, (C) N182A mutant, (D) WT GLP-1R mutant and (E) N240A mutant are shown. These micrographs are representative of two experiments.

binding ability that was displayed by the intact receptor. In the purified NT binding model, the $\mathrm{IC}_{50}$ value for GLP-1R NT was $450 \pm 35 \mathrm{nM}$, as opposed to $5 \cdot 3 \pm 1.9 \mathrm{nM}$ for the intact receptor expressed in COS-7 cells. The precise residues within the NT that interact with the GLP-1 have not been identified, but GLP-1R mutagenic studies (Van Eyll et al. 1996, Wilmen et al. 1997) and studies with other B-class receptors may serve as a basis for speculation as to their location. For the glucagon receptor, a 12 amino acid area near TM1 (aa 126-137) has been implicated. Hydrophobic residues $\mathrm{F} 184$ and $\mathrm{L} 187$ in the distal NT portion of the parathyroid hormone $(\mathrm{PTH})$ receptor were found to interact directly with the NT portion of PTH (Carter et al. 1999), and Dong and colleagues showed that the secretin receptor NT could interact specifically with Val4 of secretin (Dong et al. 1999a,b). Additionally, a naturally occurring mutation of the GH-releasing factor (GHRF) receptor (D60G) leading to a phenotype (little mice) caused by the loss of the receptor's ability to bind its ligand (Lin et al. 1993).

Despite the evidence of an interaction between the NT domain and GLP-1, the significant shift in binding affinity of the GLP-1R NT fragment suggested that the NT requires anchoring elements so that it can be appropriately presented to its ligand. Alternatively, additional binding elements may be found distal to the GLP-1R NT. The latter scenario is supported by several lines of evidence. For other B-class receptors, the EC loops and TM domains can contribute to binding. Glucagon/ GLP-1R chimera studies identified several noncontiguous domains, in the receptor, that are important for high-affinity glucagon binding, specifically at EC1, EC3, TM3, TM4 and TM6 (Buggy et al. 1995). For the secretin receptor, critical domains have been localized to EC1, EC2 and TM2 (Holtmann et al. 1996, Di Paolo et al. 1998). In addition, TM1 and TM2 for the VIP receptor have been implicated (Hashimoto et al. 1997). Conversely, GIP/GLP-1 receptor chimeric studies (Gelling et al. 1997) clearly show that the binding selectivity of GIP for the GIP receptor requires the GIP R NT domain. Interestingly, these chimerics have also been useful for examining GLP-1 binding, since the GIP(1-151)/GLP-1 R construct (CH3) also binds GLP-1 with a high affinity relative to that of the WT receptor (Fig. 5B). In comparison, GIP(1-222)/GLP-1 R (CH4) lost the ability to bind GLP-1, suggesting that the TM1-TM3 region of the receptor contains these important moieties. The advantage of these chimeric experiments over conventional loss-offunction mutations lies with the fact that these chimeric proteins retained, or gained additional, GIP binding and signaling activity (Fig. $5 \mathrm{C}$ and E), ensuring that they were appropriately expressed on the cell surface.

Although it is conceivable that any residues within TM1-TM3 may be involved in ligandreceptor interactions, the strong possibility that stable receptor-peptide complexes involve ionic interactions (intramolecular ion pairing) supports the need to examine charged residues within this region. Thus, Holtmann et al. (1996) demonstrated that two basic residues, H189 and K190, at the first EC loop of the secretin receptor may be involved in ligand-receptor interactions. Although, in the present study, several charged residues were found not to affect GLP-1R affinity, K197A, D198A, $\mathrm{K} 202 \mathrm{~A}$, and D215A and R227A displayed remarkably reduced binding affinity $\left(\mathrm{IC}_{50}\right.$ values 4 - to 


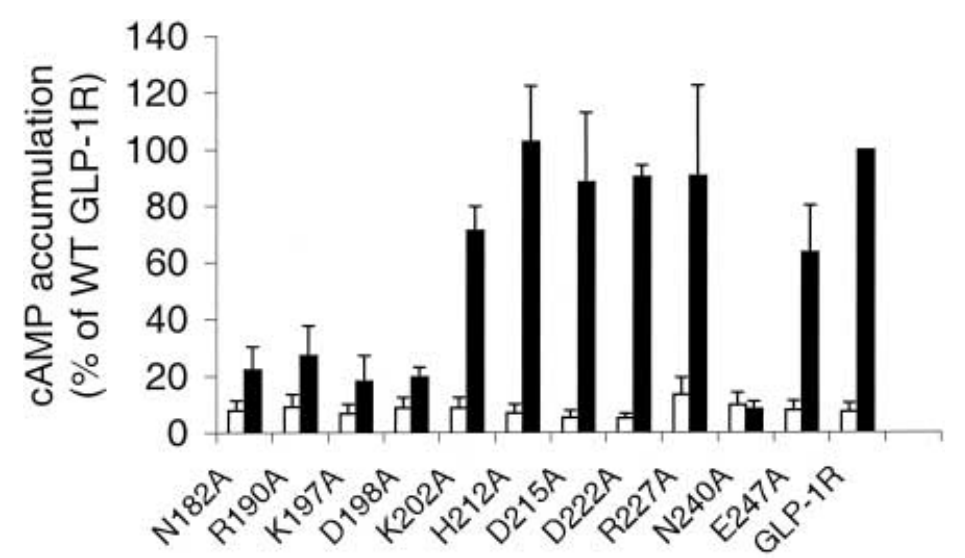

FIGURE 8. Analysis of GLP-1-stimulated cAMP accumulation in COS-7 cells expressing GLP-1R mutants. GLP-1 (10 nM) induced cAMP production in cells expressing mutant GLP-1R. Open bars represent the cAMP contents without GLP-1 treatment, whereas solid bars represent the cAMP contents with GLP-1 treatment. The values are the means \pm s.E.M. of three independent experiments.

'20-fold higher than that of WT GLP-1 receptor; Table 1, Figs 6 and 8), and this is accompanied by a reduced value for $B_{\max }$ (Table 1). Upon B-class receptor alignment, K197, and D198 and R227, are conserved in the majority of the receptors of this family. In fact, a single substitution with alanine in place of R166, K173 or D174 of the secretin receptor (equivalent to R190, K197 and D198 of GLP-1R) or in place of D196 of the vasoactive intestinal peptide (VIP)-1 receptor (equivalent to D198 of GLP-1R) affects binding (Du et al. 1997, Di Paolo et al. 1998, 1999). These data suggest that those residues are important for ligand-receptor interactions across the receptor class. In contrast, K202 and D215 are unique to the GLP-1R and are therefore more likely to contribute to binding specificity. Hence, it is conceivable that in this study, the replacement of positively charged $\mathrm{K}$ and $\mathrm{R}$ or negatively charged $\mathrm{D}$ with $\mathrm{A}$ would block the potential association with the oppositely charged residues of GLP-1, reducing affinity. Alternatively, these residues may stabilize the receptor, but this is less likely than with the residues found in the TM helices. For example, in this study, mutants with extremely low $\mathrm{B}_{\max }$ values and poor receptor activation were found in TM1 (data not shown), TM2 and TM3, and, when tagged with GFP, were incapable of being efficiently translocated and inserted into the plasma membrane (Fig. 7).

Investigations detailing the molecular structures of peptide hormones and the interactions between a receptor and its ligand may facilitate the design

www.endocrinology.org of structurally smaller, potent receptor agonists or antagonists. For example, a 4-amino-acid VIP derivative has been found to possess more neurotrophic activity than the native VIP (Gozes et al. 1999) and a small non-peptidyl growth hormone secretagogue has been produced recently (DeVita 2000). On the basis of these and other advances, future studies on GLP-1 and its receptor may uncover interactions that might provide important information for the rational design of novel small GLP-1R agonists. The present study may suggest, however, that it is not possible to produce a small molecule based on GLP-1 structure, because of the complex interactions between the peptide and its receptor.

\section{ACKNOWLEDGEMENTS}

This work was supported by grants to M B W from the MRC of Canada (MT-12898) and the Canadian Diabetes Association. We would like to thank Drs Michael Tropak and James Rini for assistance with protein production and purification, and Drs R A Pederson and $\mathrm{C} \mathrm{H} \mathrm{S} \mathrm{McIntosh} \mathrm{for} \mathrm{providing}$ ${ }^{125}$ I-GIP.

\section{REFERENCES}

Bergwitz C, Gardella TJ, Flannery MR, Potts JT, Kronenberg HM, Goldring SR \& Juppner H 1996 Full activation of chimeric receptors by hybrids between PTH and calcitonin. Fournal of Biological Chemistry $27126460-26473$. 
Buggy J, Livingston J, Rabin D \& Warren H 1995 Glucagon-glucagon-like peptide 1 receptor chimeras reveal domains that determine specificity of glucagon binding. Fournal of Biological Chemistry 270 7474-7478.

Buteau J, Roduit R, Susini S \& Prentki M 1999 Glucagonlike peptide-1 promotes DNA synthesis, activates phosphatidylinositol 3-kinase and increases transcription factor pancreatic and duodenal homeobox gene 1 (PDX-1) DNA binding activity in beta (INS-1)-cells. Diabetologia 42 856-864.

Carter PH, Shimizu M, Luck MD \& Gardella TJ 1999 The hydrophobic residues phenylalanine 184 and leucine 187 in the type- 1 parathyroid hormone (PTH) receptor functionally interact with the amino-terminal portion of PTH-(1-34). Fournal of Biological Chemistry 274 31955-31960.

DeVita RJ 2000 The production of nonpeptidyl growth hormone secretagogue. www.merck.com/mrl/speakerlist/ MRL speakers program

Di Paolo E, De Neef P, Moguilevsky N, Petry H, Bollen A, Waelbroeck M \& Robberecht P 1998 Contribution of the second transmembrane helix of the secretin receptor to the positioning of secretin. FEBS Letters 424 207-210.

Di Paolo E, Vilardaga JP, Petry H, Moguilevsky N, Bollen A, Robberecht P \& Waelbroeck M 1999 Role of charged amino acids conserved in the vasoactive intestinal polypeptide/ secretin family of receptors on the secretin receptor functionality. Peptides 20 1187-1193.

Dillon JS, Tanizawa Y, Wheeler MB, Leng X-H, Ligon BB, Rabin DU, Warren HY, Permutt MA \& Boyd AE, III 1993 Cloning and functional expression of the human glucagon-like peptide (GLP-I) receptor. Endocrinology 133 1907-1910.

Dong M, Wang Y, Pinon DI, Hadac EM \& Miller LJ $1999 a$ Demonstration of a direct interaction between residue 22 in the carboxyl-terminal half of secretin and the amino-terminal tail of the secretin receptor using photoaffinity labeling. Fournal of Biological Chemistry 274 903-909.

Dong M, Wang Y, Hadac EM, Pinon DI, Holicky E \& Miller LJ $1999 b$ Identification of an interaction between residue 6 of the natural peptide ligand and a distinct residue within the amino-terminal tail of the secretin receptor. Fournal of Biological Chemistry 274 19161-19167.

Drucker DJ 1998 Glucagon-like peptides. Diabetes 47 159-169.

Du K, Nicole P, Couvineau A \& Laburthe M 1997 Aspartate 196 in the first extracellular loop of the human VIP1 receptor is essential for VIP binding and VIP-stimulated cAMP production. Biochemical and Biophysical Research Communications 230 289-292.

EMBL 1997 Information system for G protein coupled receptors (GPCRs) at EMBL.

Fehmann HC, Goke G \& Goke B 1995 Cell and molecular biology of the incretin hormones glucagon-like peptide 1 and glucose-dependent insulin releasing polypeptide. Endocrine Reviews 16 390-410.

Gelling RW, Wheeler MB, Xue J, Gyomorey S, Nian C, Pederson RA \& McIntosh CHS 1997 Localization of the domains involved in ligand binding and activation of the glucose-dependent insulinotropic polypeptide receptor. Endocrinology 138 2640-2643.

Gourlet P, Vilardaga JP, Waslbroeck M, Vandermeers A \& Robberecht P 1996 The C-terminus ends of secretin and VIP interact with the $\mathrm{N}$-terminal domains of their receptors. Peptides 17 825-829.

Gozes I, Perl O, Giladi E, Davidson A, Ashur-Fabian O, Rubinraut S \& Fridkin M 1999 Mapping the active site in vasoactive intestinal peptide to a core of four amino acids: neuroprotective drug design. PNAS 96 4143-4148.
Graziano MP, Hey PJ \& Strader C 1996 The amino terminal domain of the glucagon-like peptide- 1 receptor is a critical determinant of subtype specificity. Receptors and Channels 4 9-17.

Gutniak M, Orskov C, Holst JJ, Ahren B \& Efendic S 1992 Antidiabetogenic effect of glucagon-like peptide-1 (7-36) amide in normal subjects and patients with diabetes mellitus New England Fournal of Medicine 326 1316-1322.

Gutniak MK, Guenifi A, Berggren LK, Holst JJ, Hellstrom PM \& Effendic S 1996 Glucagon-like peptide-1 enhances the insulinotropic effect of glibenclamide in NIDDM patients and the perfused rat pancreas. Diabetes Care 19 857-863.

Han G \& Hampson DR 1999 Ligand binding to the aminoterminal domain of the mGluR4 subtype of metabotropic glutamate receptor. Fournal of Biological Chemistry 274 10008-10013.

Hashimoto H, Ogawa N, Hagihara N, Yamamoto K, Imanishi K, Nogi H, Nishino A, Fujita T, Matsuda T, Nagata S \& Baba A 1997 Vasoactive intestinal polypeptide and pituitary adenylate cyclase-activating polypeptide receptor chimeras reveal domains that determine specificity of vasoactive intestinal polypeptide binding and activation. Molecular Pharmacology 52 128-135.

Hjorth SA \& Schwartz TW 1996 Glucagon and GLP-1 receptors: lessons from chimeric ligands and receptors. Acta Physiologica Scandinavica 157 343-345.

Holtmann MH, Hadac EM, Miller LJ 1995 Critical contributions of amino-terminal extracellular domains in agonist binding and activation of secretin and VIP receptors. Fournal of Biological Chemistry 270 14394-14398.

Holtmann MH, Ganguli S, Hadac EM, Dolu V \& Miller LJ 1996 Multiple extracellular loop domains contribute critical determinants for agonist binding and activation of the secretin receptor. Fournal of Biological Chemsitry 271 14944-14949.

Ji TH, Grossmann M \& Ji I 1998 G protein-coupled receptors. I. Diversity of receptor-ligand interactions. Fournal of Biological Chemistry 273 17299-17302.

Jordan BA \& Devi LA 1999 G-protein-coupled receptor heterodimerization modulates receptor function. Nature 399 697-700.

Lin SC, Lin CR, Gukovsky I, Lusis AJ, Sawchenko PE \& Rosenfeld MG 1993 Molecular basis of the little mouse phenotype and implications for cell type-specific growth. Nature 364 208-213.

Montrose-Rafizadeh C, Avdonin P, Garant MJ, Rodgers BD, Kole S, Yang H, Levine MA, Schwindinger W \& Bernier M 1999 Pancreatic glucagon-like peptide-1 receptor couples to multiple $G$ proteins and activates mitogen-activated protein kinase pathways in Chinese hamster ovary cells. Endocrinology 140 1132-1140.

Nathan DM, Schreiber E, Fogel H, Mojsov S \& Habener JF 1992 Insulinotropic action of glucagonlike peptide-I-(7-37) in diabetic and nondiabetic subjects. Diabetes Care $\mathbf{1 5}$ 270-276.

Nauck MA, Heimesaat MM, Orskov C, Holst JJ, Ebert R \& Creutzfeldt W 1993 Preserved incretin activity of glucagonlike peptide 1 [7-36 amide] but not of synthetic human gastric inhibitory polypeptide in patients with type-2 diabetes mellitus. Fournal of Clinical Investigation 91 301-307.

Ng GY, O’Dowd BF, Lee SP, Chung HT, Brann MR, Seeman P \& George SR 1996 Dopamine D2 receptor dimers and receptor-blocking peptides. Biochemical and Biophysical Research Communications 227 200-204.

Salapatek AM, MacDonald PE, Gaisano HY \& Wheeler MB 1999 Mutations to the third cytoplasmic domain of the 
glucagon-like peptide 1 (GLP-1) receptor can functionally uncouple GLP-1-stimulated insulin secretion in HIT-T15 cells. Molecular Endocrinology 13 1305-1317.

Sandhu H, Wiesenthal SR, MacDonald PE, McCall RH, Tchipashvili V, Rashid S, Satkunarajah M, Irwin DM, Shi ZQ, Brubaker PL, Wheeler MB, Vranic M, Efendic S \& Giacca A 1999 Glucagon-like peptide 1 increases insulin sensitivity in depancreatized dogs. Diabetes $\mathbf{4 8}$ 1045-1053.

Thorens BG 1992 Expression cloning of the pancreatic $\beta$ cell receptor for the gluco-incretin hormone glucagon-like peptide 1. PNAS 89 8641-8645.

Thorens BG 1993 Glucagon-like peptide-1 and the control of insulin secretion in normal and in NIDDM. Diabetes 42 1219-1225.

Van Eyll B, Goke B, Wilmen A \& Goke R 1996 Exchange of W39 by A within the N-terminal extracellular domain of the GLP-1 receptors results in a loss of receptor function. Peptides 17 565-570.

Wang X, Cahill CM, Pineyro MA, Zhou J, Doyle ME \& Egan JM 1999 Glucagon-like peptide-1 regulates the beta cell transcription factor, PDX-1, in insulinoma cells.

Endocrinology 140 4904-4907.

Wheeler MB, Gelling RW, Hinke SA, Tu B, Pederson RA, Lynn F, Ehses J \& McIntosh CH 1999 Characterization of the carboxyl-terminal domain of the rat glucose-dependent insulinotropic polypeptide (GIP) receptor. A role for serines 426 and 427 in regulating the rate of internalization. Fournal of Biological Chemistry 274 24593-24601.

Wilmen A, Goke B \& Goke R 1996 The isolated N-terminal extracellular domain of the glucagon-like peptide-1 (GLP)-1 receptor has intrinsic binding activity. FEBS Letters 398 $43-47$.

Wilmen A, Goke B \& Goke R 1996 The isolated N-terminal extracellular domain of the glucagon-like peptide-1 (GLP)-1 receptor has intrinsic binding activity. FEBS Letters 398 43-47.

Wilmen A, van Eyll B, Goke B \& Goke R 1997 Five out of six tryptophan residues in the $\mathrm{N}$-terminal extracellular doman of the rat GLP-1 receptor are essential for its ability to bind GLP-1. Peptides 18 301-305.

Xu G, Stoffers DA, Habener JF \& Bonner-Weir S 1999 Exendin- 4 stimulates both $\beta$-cell replication and neogenesis, resulting in increased $\beta$-cell mass and improved glucose tolerance in diabetic rats. Diabetes 48 2270-2276.

RECEIVED 25 May 2000 